\title{
The People Who Occupied The Fallen Angels' Chairs in Heaven: A Reiterated Idea in the Fifteenth Century, the Valencian Golden Age
}

\author{
MARCO ANTONIO CORONEL RAMOS
}

Universitat de València

\begin{abstract}
Johannes Ludovicus Vives (1493-1540) repeatedly used the symbolic image of humans occupying the fallen angels' chairs in heaven. In fact, the purpose of the creation of human beings seemed to be to occupy those empty chairs in paradise. This article focuses on the recurrent presence of that idea in the Valencian literature of the fifteenth century. It was a thought that was widely accepted even among people of a limited educational background. This paper supports the idea that Vives was the scholar who took this well-known belief from his homeland and introduced his Erasmian circle to it. That process of dissemination is described and explained by quoting some fragments of the most important Valencian authors of that time and other, representative, members of Spanish Erasmism.

Resumen

Juan Luis Vives (1493-1540) utilizó repetidas veces la imagen simbólica de los hombres ocupando las sillas que los ángeles caidos habían dejado vacías en el cielo. De hecho, la creación del ser humano se justifica como una manera de ocuparlas. El presente artículo se centra en este pensamiento que fue recurrente en la literatura valenciana del siglo XV. Tuvo tanta difusión que era conocido incluso en los estratos más populares de la sociedad. En este trabajo se defiende que Vives pudo ser uno de los divulgadores de esta metáfora entre su círculo de intelectuales erasmistas. El proceso de divulgación queda descrito y explicado con la cita de fragmentos tomados de los autores valencianos más importantes de la época y con otros provenientes de algunos representantes del erasmismo español.
\end{abstract}

The specific purpose of this paper is a matter of detail: one that distinguishes the work of a philologist, in this case to pursue the history of an idea that, after having emerged in Valencia again and again, appears in the Diálogo de Doctrina Christiana (Vives 2009), published anonymously in 1529, in which the following fragment can be read: 
Éste [Lucifer], movido con loca y temeraria presunción, quiso poner su silla cabe el muy alto Dios y ser semejante a él, y en pena de su loco y desvariado atrevimiento echó Dios de allá del cielo a él y a los otros ángeles que fueron participantes en aquella maldad y atrevimiento, y los puso adonde para siempre jamás ternán grandíssimos tormentos y trabajos. Hecho esto, viendo Dios que aquellas sillas que los ángeles malos avían perdido estaban vazías, quiso criar el linaje humano, para que las posseyessen aquellos que le fuesen obedientes. Las quales, porque avían sido primero perdidas por sobervia, quiso se ganassen por humildad. (Vives 2009: 634-35)

In another article (Coronel Ramos 2018), I studied the importance of this image to understand Renaissance anthropology and, at the same time, to encompass the relevance of angelology to descriptions of the human world by some humanist authors such as Juan Luis Vives. The topic of people occupying the fallen angels' chairs emerged in the same period as a way of recognizing the dignity of the human being, who was created to enjoy the presence of God in the company of the angels. Juan Luis Vives (1493-1540) exemplifies the frequent use of this type of metaphor, inherited from the literature of his homeland, Valencia, where, as this article will show, it was widespread.

One of the outstanding fragments in this sense is without doubt the end of the Fabula de homine (1518), in which Vives describes the gods taking delight in humans:

$[\mathrm{H}] \mathrm{aec}$ atque alia dii contuentes quum non teneret eos satietas, haud secus ac qui in speculo suam intuentur formosam imaginem, delectantur ea, nec gravate diutius immorantur, sic illi, quum et se et patrem ipsum Jovem in homine tam expressos viderent, juvabat eos quae jam saepe viderant, saepius conspicere [...]. (Vives 1783: 7)

[The gods, contemplating that and other things, since they were not at all tired, take delight in it in a way not unlike those who observe their beautiful image in a mirror, willingly lingering for a while. In this way, they, seeing themselves and father Jupiter so well reflected in man, rejoiced in witnessing more often what they had often seen.] (my translation)

If deities can gaze into themselves by watching human actions, it will not come as a surprise that they invite humans to take a seat among the gods, and occupying precisely the front rows:

[T]antum abest ut dii ex amplissimo ordine fastidierint hominem paullo antea histrionem; acceptus ab illis honorifice, et ad primas sedes invitatus, sedit immistus eorum catervae, inde ludos spectavit, qui suo semper tenore persecuti sunt. (1783: 8)

[It is completely absurd that gods in common agreement could despise the man, who until recently was an actor. After receiving him with honors and inviting him to occupy the first rows, he sits in the middle of the crowd of those, from where he attended the performances that continued in the usual manner.] (my translation)

The Fabula de homine is constructed like a pagan fable, but its meaning does not stray from the passage from Vives' Diálogo (2009: 634-35), quoted above, in two senses: (1) humans deserve to take a seat in the highest part of heaven; and (2) these places are shared by humans and gods -the latter taking the role of angels in the Fabula. These two points are essential to the claim for human dignity, and 
in some manner are present in the works of several Spanish authors. Vives, for example, alludes to the same image in Meditationes in septem psalmos poenitentiales (1518) with the following words blurted out against the devil:

Credo, tamen, quod te illud solum urit, quod sis me tua in sede locatum visurus. Ideo tam sollicite tam anxie laboras, non modo ut ego hac frustrer tanta spe, sed ut supernis illis sedibus beatissimis istas tuas infernas miserrimas consequar. (1782: 248)

[Now, I think you are enraged by the fact that you have to see me occupying your seat. That is why you make an effort with so much worry and anguish not only for me to be frustrated by that great hope, but also for me to reach your hellish seats full of misfortunes instead of those celestial ones full of happiness.] (my translation)

That reference seems to have been well known in Spanish Erasmian circles. Some conspicuous examples are Bernardo Pérez de Chinchón (1448-1556), Bernal Díaz de Luco (1495-1556), Francisco Cervantes de Salazar (c. 1513-1575) and Martín Reina (fl. sixteenth century). All of these writers are related to Vives or to the Erasmian movement. The first, Pérez de Chinchón, was born in the city of Gandia, becoming a canon of its cathedral. He was renowned for some religious and apologetic works. The achievement that brought him real fame was, however, having translated some works by Erasmus and Vives into Spanish, for example, La lengua ... (1533) (Erasmo de Rótterdam 1975). The presence of the image in question in the preface of that translation is not surprising considering that he was living in Valencia - like Vives - and intellectually fitting into Erasmism. Pérez de Chinchón compared Creation to the making of a sculpture and God to Daedalus. In this context the human sculpture, commonly imagined as a microcosm, replaced the broken part of the angelic sculpture:

La natura angélica estatua fue, y hermosíssima: qué atadura le puso Dios, cómo se le quebró, cómo mucha parte della se cayó, cómo quedó firme un pedaço de la estatua, cómo Dios la remendó con naturaleza humana, no me quiero aquí parar a dezirlo, pues mi plática va enderesçada a otro fin. Solamente quiero dezir del hombre, que fue una de las estatuas que hizo Dios en que más mostró su arte y sabiduría. (Erasmo de Rótterdam 1975: 4-5)

The same image can be found in the Aviso de curas (1543) by Juan Bernal Díaz de Luco, bishop of Calahorra and member of a group of Catholic reformers, also including personalities such as Hernando de Talavera, all of whom were prelates looking into the moral and intellectual reform of the Church (Díaz de Luco 1962; Gómez Marín 2001; Colahan and Masferrer 2007; Coronel Ramos 2012; 2013). Díaz de Luco wrote two works that fitted into this field of reform: Instrucción de perlados (1530) and Aviso de curas (1543). The Aviso, published in one of the most relevant Spanish Erasmian venues, Alcalá de Henares, contains the following two passages: (1) 'Pues quesiste antes ayudar a los demonios a poblar los infiernos, que a los ángeles a poblar las sillas que ellos perdieron'; and (2) 'quejarse han de ti los ángeles universalmente que, por ser tú tal, se cumplió más tarde el número de sus hermanos, y se dilató el reparo de las sillas vacías del cielo’ (Díaz de Luco 1996: 150, 151). 
Another important Spanish Erasmist was Francisco Cervantes de Salazar (c. 1513-1575), who died in Mexico and had introduced the New World to Spanish Humanism (Bono 1991) and, particularly, to the writings of Vives, editing Commentaria in Ludovici Vives Exercitationes Linguae Latinae (1554) (Cervantes de Salazar 1986) and his translation Introducción para ser sabio (Vives 1544). Besides theses works, his fame grew thanks to his Crónica de la Nueva España (1575) (Cervantes de Salazar 1971), in which the image in question appears four times: (1) '[Lucifer] echado del cielo, viendo que, aunque engañó al primer hombre, le levantó Dios hasta ponerle en el asiento que él perdió' (1971, I: 131); (2) 'A éste [Lucifer] y a ellos llamamos diablos, que quiere decir cabiladores, porque con el pesar que tienen de que el hombre suba al asiento que ellos perdieron, procuran con gran cuidado, quitando la honra al verdadero Dios, tomarla para sí, haciéndose adorar de los hombres como si fuesen verdaderos dioses' (1971, I: 202); (3) 'Para que su sancta fee se plante y el demonio pierda la silla que tanto tiempo ha tenido usurpada' (1971, II: 135), and (4) ‘O por usar de mayor misericordia y creer que por otros medios que nosotros pensábamos, el demonio perdiese su antigua silla' (1971, II: 167).

Among the Erasmian quoted authors, Martín Reyna should also be mentioned. He translated and adapted into Spanish the Liber de moribus hominum et de officiis nobilium super ludum scacchorum (1549) written by the Lombard Jacobo de Cessolis (Cessolis 1879; 2005; Burt 1957). It was published in Valladolid with the title Dechado de la vida humana moralmente sacado del juego del axedrez (Reyna 1952). Previously this Liber de moribus had been translated into some European languages (Scolari 1989; 2001; Bataller Catalá 2000), including Catalan (Cessolis 1900; 1902; Bataller Catalá 2009). One of his most relevant additions was the story of Orpheus and Euridice. He explained that story in a symbolic manner, concluding:

Venidos a la declaración de la burla passada, veremos clara y abiertamente la verdad. Que otra cosa es este gran philósopho Orpheo, salvo el verdadero Dios y omnipotente criador, el qual con sola su voz y armonía crió el mundo, y con sola su palabra crió todas las cosas, porque en el principio crió Dios el cielo y la tierra [...]. Esta Euridice de quien tan enamorado fue Orpheo, que otra cosa sino la natura humana, por la qual verbum caro factum est. Porque se casó con ella, quando la sacratíssima Virgen María, nuestra abogada y señora, fue requerida de amor del Ángel Gabriel [...]. Luego que Dios crió al hombre, vio que avía de peccar y dixo: pésame aver hecho el hombre, que exponen y declaran los theólogos, yo haré penitencia sobre la tierra por el hombre, y esto fue lo que la fábula dize, que Orpheo, después de aver gozado de Eurídice, estuvo un poco tibio en su amor. Criado nuestro primero padre Adam, y nuestra madre Eva, fueron puestos en el paraýso terrenal, a la qual [...] la serpiente engañó. Esto es lo que la fábula dize, que la serpiente mordió a Eurídice y murió, y baxó al infierno, pues por la culpa del primero padre, todos yvan al infierno, mas como Dios vio tanto daño en el humanal linaje, en cuya hechura se avía deleytado, proque la más maravillos obra que Dios hizo fue la creación del hombre, como ánima intelectiva, y como le quería para henchir las sillas de los ángeles dañados y vio su culpa, (como el buen pastor) acordó buscar remedio a sus ovejas. (Reyna 1952: $\mathrm{LIVv}^{\mathrm{O}}-\mathrm{LVr}^{\mathrm{O}}$; italics in the original) 
Thus, Reyna identified redemption with the task carried out by Orpheus when returning his wife, Eurydice, from Hell. Neither the Latin original version nor the Catalan translation used this symbolic fable, which is one of the Reyna's additions. He imagined redemption as an effort to return humans - 'ánima intelectiva' - to heaven. As Reyna said, God created humans because 'le quería para henchir las sillas de los ángeles dañados'. In this way, redemption was a matter of necessity as humans were only able to occupy these chairs if they were redeemed from sin - 'acordó buscar remedio a sus ovejas'.

But one of the most surprising appearances of this metaphor occurs in Los trabajos de Persiles y Sigismunda (1617) by Miguel de Cervantes. This novel is considered a 'Christian romance' (Forcione 1972) or a 'novela de peregrinación' (Deffis de Calvo 1999). In fact, when Auristela, later baptized Sigismunda, wanted to be informed about the Catholic faith, the penitenciarios said:

Comenzaron desde la invidia y soberbia de Lucifer, y de su caída con la tercera parte de las estrellas, que cayeron con él en los abismos; caída que dejó vacas y vacías las sillas del cielo, que las perdieron los ángeles malos por su necia culpa. Declaráronle el medio que Dios tuvo para llenar estos asientos, criando al hombre, cuya alma es capaz de la gloria que los ángeles malos perdieron. (Cervantes 1999: 441)

This quotation is the nearest to Vives' (2009) Diálogo de doctrina Christiana, while beginning the relationship of the principles of faith with the fall of the angels and specifying that the reason for the creation of humans was to remedy that same fall. Both ideas result in the vindication of human majesty.

Summarizing this section, it is noteworthy that the metaphor of humans occupying the fallen angels' chairs was quite well known among Spanish humanists who were related in some way to the Erasmism movement. Its presence stands out in the works of Vives to underline the issue of human dignity. He could easily have known of it in his native Valencia and perhaps he spread it in Erasmian circles. In Valencia, this metaphor had developed in two different ways: (1) to clarify the holiness of humans, and (2) to underline the veneration owed to the Virgin Mary, who was the first human to enjoy that holiness in her seat in heaven. This latter use can also be applied to the saints. Vives knew all those usages and was likely to have been the link by which this image was transmitted from Valencia to Spanish Erasmism; and perhaps he was even the source for its use by Cervantes, given the similarities between the cited passages in the Diálogo de doctrina Christiana and in Persiles y Sigismunda.

\section{Valencia and the saints occupying the fallen angels' chairs}

In Catalan poetry, the most general meaning of the studied image leads to the identification of the humans seated in heaven with the chorus of the saints, consisting of a gathering of humans and good angels. That is the reason why Pere Serafí depicts John the Baptist as an angel whose chair was connected with Lucifer: 
Àngel sou per gràcia dit,
hon posseÿu la cadira
que perdé lo malehit
Lucifer per gran ira,
d'umil tenint gran valor
en les celestials zones,
segons dix lo Salvador
en vostres lahors tant bones (Serafí 2001: 367; italics in the original)

Such assertions were usual in Catalan literature. This is demonstrated by Ramon Llull (1232-1311), who explained the triumph of the saints who resorted to that metaphor: 'Com lo nombre serà complit dels sancts qui siuran en la Glòria, en les cadires d'on los demonis són caüts, adonchs serà resurrecció general de bons e de mals, e tuyt vendran hoyr la darrera sentència, de la qual nul hom no.s pot appellar ne escusar' (1987: 62). Consequently, it is safe to assume that the Resurrection at the last day will conclude with humans occupying the fallen angels' chairs.

Consistent with these arguments, Francesc Eiximenis (1330-1409) defended in Lo libre de les dones the dignity of married life, one of whose duties is to bring children into the world. Married people will be able to occupy the heavenly chairs depending on the righteousness of their earthly life:

Lo setèn bé principal que davayla del matrimoni sí és reparació de les cadires de Paradís. Car diu Orígines en la omelia Dels Àngels que les cadires buydes del cel, qui foren d'aquells demonis qui·n són caeguts, per los sants hòmens seran reparades, los quals lo món aquest rehep de Déu a provar-los açí, e-lls fa néxer e davaylar per via de matrimoni. E seguexe: lo sant sagrament, donchs, del matrimoni fort deu ésser amable e honrat, per lo qual los àngels esperen que seran lurs cadires reformades. (Eiximenis 1981: 117)

Lo libre de les dones, after an earlier medieval version (Wittlin 1983), was translated again into Spanish and published in 1542 in Valladolid with the title El carro de las donas. This Castilian version should be described more as an adaptation than as a translation, because it adds some chapters presumably written by the translator, as well as some relevant parts taken from Vives' De Institutione foeminae Christianae (1524 and 1528). The passage in Catalan quoted above is rendered as follows:

Se trata del séptimo bien del matrimonio, el qual es la reparación de las sillas del paraýso. Por que dize Orígenes, en los libros que hizo De los ángeles, que aquellas sillas que perdieron los malos angeles por su sobervia, por consentir con Lucifer en aquella maldad, éstas han de ser cobradas y tornadas a hinchir de sanctos varones y mugeres por los bienes que en este mundo hizieren y por la misericordia de Dios. Y son tantas estas sillas que dize sant Juan en su Apocalipsi que, contando la muchedumbre por las tribus, aún después vido muchedumbre de ánimas sanctas que no las pudo contar, las quales ánimas sanctas ha embiado y embiará hasta la fin [d]el mundo, las quales son produzidas y criadas de Dios en el mundo por causa del sancto matrimonio. Por lo qual deve ser el sancto matrimonio muy tenido, estimado y acatado, pues por medio dél se cobra y repara tan gran bien perdido por aquellos malaventurados ángeles sobervios'. (Clausell Nácher 2007, I: 375-76; italics in the original) 
The wording of the adaptation offers some interesting points: (1) the Castilian script specifies the reason why the angels had fallen: the sobervia, their arrogance towards their creator. The coincidence in the use of this word in the Diálogo de doctrina Christiana, in Persiles and in El carro de las donas should not be overlooked. (2) The Castilian translation clarifies and explains that 'varones y mugeres' will be able to reach those chairs 'por los bienes que en este mundo hizieren' and 'por la misericordia de Dios', that is, the way to accomplish the final victory is specified: doing good deeds and receiving God's mercy. This version opts for a phrasing which emphasizes the orthodoxy established concerning the steps that have to be taken to achieve salvation - the chairs -, i.e., the deeds as much as mercy. Interestingly, when comparing the Catalan original and the Castilian version it becomes clear that the translator took the liberty of moving the defence of married life, highlighting its importance in fostering the continuity of human life on Earth, to the end of the passage. He chose the beginning of the passage to focus on summing up the two most common ways of salvation. He returns to the same thought in one of his most important additions: the entire book titled Aparejo para bien morir, where the following quotation can be read:

Mira, hombre peccador, de qualquier estado que seas tienes miserable batalla y guerra toda tu vida, con tan grandes y perversos enemigos, y silla tan trabajosa como es esta triste vida. La verdad es que en tanto que el hombre vive en esta vida, unos hazen silla en el cielo con buenas obras, y otros en el infierno con malas. Christiano, mira bien lo que dice la bienaventurada Virgen nuestra Señora en el Psalmo De Magnificat: Derrocó Dios y abaxó a los sobervios de su silla. Derrocó a Lucifer y a los ángeles malos que le siguieron de las sillas del cielo, como lo dize el propheta. Y derrocó a nuestros padres Adán y Eva de la silla del paraýso terrenal por el peccado de la desobediencia; derrozó al rey Saúl de la silla de rey por no obedescer a Dios, e muy grandes y muchedumbre de gentes ha derrocado Dios de sus sillas y puesto en el infierno por su sobervia. E la Virgen, nuestra Señora, dice que Dios nuestro Señor ensalça a los humildes y les da silla en el cielo. Pues, hombre peccador, trabaja en este suelo, con humildad y oración ruega a Dios te dé su gracia para que entres en la batalla de la muerte con las armas ya dichas, y con el favor de nuestro mismo Dios ayas victoria de la muerte, y te dé la silla de gloria. (Clausell Nácher 2007, II: 493)

As can be seen, the theme of the chairs has been generalized to describe each period of human life. Current life will be a 'silla tan trabajosa', on which humans build a permanent chair in heaven or in hell. Once again, the translator highlights deeds as a spur to the individual's sense of responsibility for salvation. This assertion is stressed with some examples, also referring to the wording of the Diálogo de doctrina Christiana: 'soberbia' and 'humildad'. He gives prominence to this dichotomy with the example of the Virgin Mary, whose Magnificat also contrasts with that binomial. The cases of Lucifer, Adam and Eve and King Saul are consistent with the words of the Virgin Mary, and demonstrate that pride and disobedience are contrary to God's will.

This train of thought occurs again and again in the so-called Valencian Golden Age. Some illustrious examplars are Bernat Fenollar (1439-1516), Jaume Gasull 
(at the end of the fifteenth century) and Isabel de Villena (1430-1480). The first of these, Fenollar, reiterates in the following verses the topics mentioned:

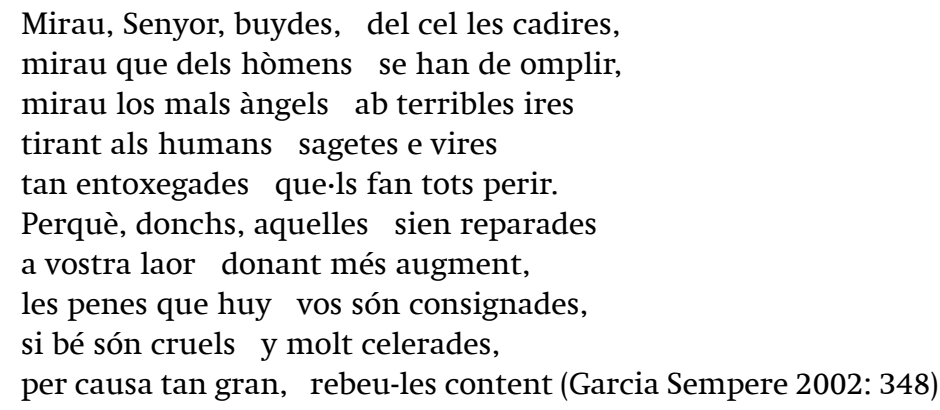

The metaphor of the chairs is therefore related to the Christian way of life based on humility. In the fight to achieve that ideal, the devils are always trying to harm humans in order to prevent them from reaching the heavenly chairs. Taking those arguments into account, it will be easy to understand that Sor Isabel, whose Vita Christi (1497) was well known to Fenollar and the other poets of his generation, requested God's help for humans to win their battle against evil and to reach the empty chairs in heaven: 'Sia de vostra divina clemència atorgar a aquests miserables fills d'Adam la petició sua, e que ixquen d'aquella dura captivitat e vinguen a lloar la majestat vostra e a posseir estes cadires qui estan buides per lo caïment d'aquells superbos àngels' (Villena 2011: 84).

The subsequent developments of this image are clear and derive from the same conception of human life as a fight against the Devil. The possibility of winning the battle defines the inner greatness of humans, who, in spite of being sinners are able to overcome their weaknesses by effort, doing good deeds and receiving divine mercy. That final victory is comparable to a heavenly chair. Thus, Jaume Gasull also portrays Christ's Cross as a chair:

$$
\begin{aligned}
& \text { cadira gran on triümfà } \\
& \text { lo rei dels reis, } \\
& \text { estrado ric on les dos lleis } \\
& \text { han reposat. (Gasull 1989: 52-54) }
\end{aligned}
$$

Consistent with these words by Gasull, Fenollar explains that Christ's death made it possible to reoccupy those chairs: 'A vós ha plagut, morint, que $\cdot \mathrm{s}$ reparen / aquelles cadires qu-inffern despoblà' (Garcia Sempere 2002: 436).

The metaphor of the chairs remained alive in the sixteenth century, as exemplified by Vives and the Erasmian movement, but also in popular poetry. One instance is an anonymous romance collected in the Silva de romances:

y aquesto siendo acabado

don Carlos tiene destar

abraçado con la cruz

que dios nos manda abraçar

en el monte donde Christo

a la nona fue a espirar 


\author{
y donde allí dara el alma \\ a quien se la quiso dar \\ para gozar en su gloria \\ sobre tanto trabajar \\ entronizado en la silla \\ que lucifer fue a dexar \\ eternalmente glorioso \\ fruyendo con descansar \\ viendo la essencia diuina \\ do no hay más que dessear \\ lo qual dios nos dexe ver \\ y assí lo quiera otorgar (Rodríguez-Moñino 1970: 204-205)
}

Consequently, only Christians will obtain a heavenly chair, as is pointed out in El Baldo (Sevilla, Dominico de Robertis, 1542): 'Pero por esso no dexan de penar, porque les faltó el creer, [pagan people] con que ninguno, d'ello caresciente, podrá penetrar las sillas celestiales' (Gernert 2002: 136). The reason for justifying this assertion is the contrast between the excessive pride of devils and the humility of saints. The Christian way of life is determined by its final triumph in choosing humility.

\title{
The Virgin Mary shows the way
}

Although the dogmatic definition of Mary's Immaculate Conception and of her Assumption date from 1854 and 1950 respectively, Spain in general and the Kingdom of Valencia in particular had been promoting those beliefs for centuries (Ruiz-Gálvez Priego 2008; Callado Estela 2013) with the close co-operation of, among others, the ubiquitous Franciscan Order. Belief in the Immaculate Conception was very widespread in Valencia in the fifteenth century especially, and a source of interminable debates among theologians, which left their marks on the different arts (Stratton 1989; Alejos Morán 2005). If Mary's Immaculate Conception meant that she was preserved from Original Sin, her Assumption represents the consequence of that privilege. These beliefs strengthen the role of Mary as a model for all humankind and, particularly, for women (Ruiz-Gálvez Priego 2006). In fact, human fate is mirrored in Mary's life, whose culmination is to reach heaven and to be seated on a chair there, to enjoy the eternal contemplation of God. Consequently, this belief led to the image of Mary taking one of those chairs, presumably one that pertained to a fallen angel.

One work in which these facts can be clearly appreciated is sor Isabel de Villena's Vita Christi, whose core is Mary's Immaculate Conception and her Assumption. Mary's heavenly life is held to be the mirror of the afterlife for every good Christian. Therefore sor Isabel, who was strongly influenced by the Evangelium Nicodemi, one of the basic apocryphal texts for medieval literature (Izquierdo 1997; Fradejas 2005: 443-60), did not find any a better example of life to propose to her nuns (Villena 2011: 542-44, 569-70; Twomey 2013: 42-62), particularly in light of the Assumption, as that belief focuses human fate on its final victory. 
Logically, the Assumption was preceded by Christ's Ascension in a predictable chain that links Christ's victory over Satan, sin and death with the possibility for humans to reach heaven. Christ's elevation is also underlined by his action of occupying a heavenly seat. So when Christ reached heaven, 'regracià a la majestat del Pare seu la glòria e exaltació que donada li havia; e, feta profunda reverència a sa clemència, sigué en l'alta cadira dignament a sa altesa preparada' (Villena 2011: 518).

This conventional depiction is followed by Christ's speech addressed to those awaiting his Resurrection: 'E ara, venint e retornant en lo cel, on és l'eternal posada mia, he portat en companyia mia tota la presa que d'infern he treta, los quals vull col-locar entre vosaltres, esperits angelicals, per reparar les cadires per los desobedients e rebel-les àngels perdudes' (2011: 519). Sor Isabel employed powerful images of Christ's invitation for each saint to occupy the fallen angels' chairs, i.e. Adam and Eve, Joseph, Anne and other saints are seated among the seraphim (519-20), who expressed their joy that all empty chairs had finally been taken:

E tot l'orde dels serafins, molt inflamats e gojosos de la gent tan excel-lent que entre ells era aposentada, e veent així ben reparades les sues cadires e que encara esperaven que fins a la fi del món en aquell orde serie col-locades multitud de persones de singular magnificència, regraciaren e molt exalçaren la caritat divina, que tan complidament havia reparat los órdens angelicals ab los hòmens remuts. (Villena 2011: 520)

John the Baptist, Isaiah, Ezekiel, Daniel, doctors, teachers and preachers occupied chairs among the cherubim; patriarchs and those who had received the revelation of divine mysteries such as Melchisedec and Elizabeth were seated among the thrones; Abel, the innocent saints and other martyrs among the dominions and lordships; Moseh and other priests among the principalities and rulers; Eliah, Enoch, King David, Judith and Esther among the powers and authorities; the kings who administered justice among the virtues and strongholds; those who are in charge of the communities such as Jeremiah and Tobias among the archangels; and, ultimately, those who are the protectors of humans among the angels (521-31).

These pages of Villena's Vita Christi constitute one of the most outstanding allegories expressing in popular words the concept related to the heavenly chairs. The parallelism between the assembly of saints and angels is stressed by describing the unique celestial community formed by those who were awaiting the advent of the new period of mercy (517). The saints are the holy people who were born before Christ. After Christ's Ascension, when the era guided by the Holy Spirit is to begin, the Virgin Mary will be the first human to occupy a chair. Hence, the celestial assembly formed by saints and good angels will be complete. This is expressed by Fenollar in the lines 'Mirau los bons àngels volent companyia, I Senyor, de nosaltres, d'amor ab gran zel' (Garcia Sempere 2002: 348).

This belief corresponds to the narration of the Assumption of Mary outlined above (Villena 2011: 547-63), whose first expected step is the angels placing her 
chair near her son's in heaven: 'E primerament entraren en la cambra quatre àngels portant catifes e coixins, e dos excel-lents cadires, e feren lo estrado molt singular e solemne per a seure lo Senyor e redemptor nostre e la excel-lent mare sua' (2011: 563). Finally, all saints and angelical hierarchies revere Mary as she is seated near Christ: 'E tornant lo Senyor en la cadira, manà seure la senyora mare sua molt prop de si' (509).

A similar case is La vida de la Sacratíssima Verge Maria (1494) by Miquel Peres, whose words are a reminder of those from Sor Isabel's Vita Christi: 'Per exalçar a natura humana sient a la dreta part de Déu lo Pare, y per reparar tota natura angélica ab la sua corporal presència' (Arronis Llopis 2015: 339). The constant appearance of these symbols shows how these thoughts were rooted in the Valencian culture of its Golden Age.

These popular stories were usually related to the Immaculist movement (Ferrando 1983: 71-72). This assertion can be justified by reference to the various poetry contests held in Valencia to commemorate the privileges given to Mary. Thus, if the Cross had been compared to the chair, Mary's belly would also be named cadira:

¡Quant sotz vós més, de tot edicte fora, cors gloriós, pus çell que.1l cel adora ha reposat dins vós e pres cadira! (1983: 63)

Perhaps the preponderance of Immaculist - and eucharistic - themes in contemporary Valencian poetry could be linked to the presence of strongly rooted Jewish and Islamic communities in Christian Valencia (1983: 67). This statement becomes clearer when the converso community is added, which was perhaps the most influential social group in Valencia. Christians defended their faith against all of these groups by using all the resources available, including disseminating topics such as the metaphor of heavenly chairs and others related to it, like, for example, the postulate of a unique heavenly community composed by saints and angels $(75,274,283,314,318,590)$. The image was so common that it was not necessary to develop it entirely. A vague reference or allusion was enough to bring back the whole allegory. This is the case in the following poem by Joan Roís de Corella, published in the Certamen en lahors de la Verge Maria (1474), supposedly the first literary book printed in Spain. The poet alludes to the Resurrection and Ascension of Christ, who prepared the chairs for redeemed people among the seraphim. The wording of the poem reminds us of Villena's Vita Christi:

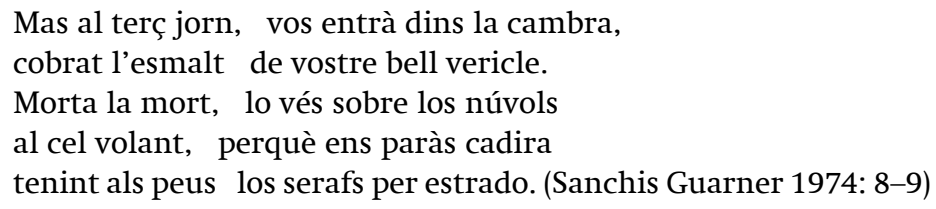

Later, the tornada presents the predictable reference to Mary seated in heaven after having become the main mediator between God and humans (Ferrando 1983: 282, 329): 
Deu anys e dos dels apòstols maestra

Déu vos deixà, perquè $\cdot 1 s$ fósseu refugi,

ffins que pujàs, tenint en la mà [c]eptre

alt, sobre els cels, passant lo més alt cercle,

ab cors pus cla[r]s que relluent carvoncle,

emperadriu, sient a la part dreta. (Sanchis Guarner 1974: 9)

The last line of that tornada evokes another topic: the assertion that Mary is seated above all the saints, as also told by Johan Gamiça and Mossén Jerònim Fuster (Ferrando 1983: 284, 440). Roís de Corella therefore asserted that Mary deserved to be worshipped by the angels: 'Doncs, mereixeu los àngels vos adoren, puix lo qui els féu, servint així us adora' (2014: 340).

Further expressions such as ciutat de Déu, dels exel-lats refugi and cancellera de Paradís, used by Valencian poets again and again, are reminders of Mary's indispensable mediation to promote human salvation, for example, to reach to the celestial chairs.

Ciutat de Déu, dels exel-lats refugi;

quin goig tingués com vostre Fill il-lustre

tornà del cel, dient-vos: 'Cancellera

de Paraís, veniu a la cadira!

La vostra mà tenint sobre lo muscle

d'aquell gran Déu, a qui pogués concebre!

Pujàs tan alt sobre les jerarquies

como los serafs estan sobre los àngels'.

(Roís de Corella 2014: 341-42)

Seated in her chair, Mary also keeps the keys to paradise. Thus, she received the name of cancellera in Corella (Ferrando 1983: 334) or clavera in Jerònim sent Pere (1983: 857) or in the following poem by Joan Sobrevero:

Del cel sóu escala i digna clavera.

Atèny[e]r la glòria sens vós no es comporta, car sóu la llanterna mostrant la carrera.

Teniu la reguarda portant la bandera.

Als bons qui us serveixen, obriu vós la porta.

La mort tan amarga sentís molt agresta, que trist, per nos rembre, Jesús prés en terra.

En tots vostres actes portàveu conquesta de l'alta cadira, on, d'àngels la festa rebeu, tan solempne, que infern s'aterra

(Sanchis Guarner 1974: 95-96)

Mary's chair had become the starting point from which the most exceptional Valencian poets developed a string of topics. In addition to those mentioned here, the theme of her humility, present in the quotation from the Diálogo de Doctrina Christiana at the beginning of this paper, is central as it highlights the path that humans should follow. That was the reason why she obtained la cadira més digne, as expressed by Lluís Català: 
Sola sens par, dels cels la més insigne,

de puritat teniu ornat vestir;

al què valeu, la corona condigne,

lo loch pus alt, la cadira més digne,

que maternal se pogués elegir (Ferrando 1983: 309)

Summing up, Mary's chair had been gained because of her collaboration against evil - De Sathanàs partís lo cap en peçes (Ferrando 1983: 306) or Lo gran Sathan haveu ferit ab verga (1983: 303). The most direct consequence of this is the fact of her having been kept away from any sin:

No us ha pogut fer nafrar la vostr. arma

lo vil Satan ab la seu cruel vergua,

d'aquell peccat original. (303)

Consequently, she is compared by Narcís Vinyoles to the burning bush of Moses, 'de Moysés foguejant gavarrera', becoming in Matheu Esteve the boatman Charon, who is able to open the gate to paradise, 'Caron sou vós, del cel, dich, la barquera' (329). For this reason, in the words of Narcís Vinyoles, she can be considered the one who re-established the empty heavenly chairs, 'De parahís reparau les cadires' (306). The following words, written in the Valencian Certamen en prosa plana en honor de la Inmaculada (1487), could be considered the perfect conclusion of this paper, because they describe accurately the position of privilege occupied by the Blessed Virgin in Heaven and justify the crucial importance of Mary's devotion in Valencian society:

¿Qui seu sobre los cors dels àngels en la suprema cadira sinó vos, que sola posseÿu la quarta y més alta jerarchia? Los àngels, si trihunfen per puritat en glòria, vós més gloriosa, per ser pura concebuda e stau aprés Déu eternalment col·locada; més alta és, donchs, la vostra puritat, majors són los dons que vós devíeu pendre com a subjecte més perfet. (550-51)

\section{Conclusion}

Taking into account the great many examples from the numerous authors cited, the symbol of the fallen angels' chairs was actually rather widespread and popular. The recurrence of that motif in Isabel de Villena is more than evident proof of this popularity. The Immaculist movement and the great devotion to the Archangel Michael in Valencia - and the Àngel Custodi or Angel Protector of the city and its kingdom - also contributed to the vast propagation of the metaphor (Eiximenis 1958; 1988). Hence, it is unsurprising that the Virgin Mary, seated on her heavenly chair, was chosen to embody the position of intercessor for humans to reach salvation. In that sense, Roís de Corella defended the Immaculate Conception, dreaming of Mary seated at the top of a sort of Scala Sancta, thus indicating that she occupies the highest position in heaven (López Quiles and Puig Gisbert 2014: 265-79. The dissemination of these ideas was so ubiquitous that Joan Scrivà renders Christ's Incarnation as his descent from his 
heavenly high chair: 'Recort deu tenir com, d'alta cadira / al món devallant, de carn vos cobrís' (Garcia Sempere 2002: 419).

These metaphors remained popular themes in Catalan poetry during the sixteenth century. The poem 'Atra obra en lahors de nostra senyora de Esperança' by Pere Serafí (1505-1567) is a case in point:

Los àngels, vent aquella gran cayguda

que despullà del cel tantes cadires, ab gran fervor cantaven la vinguda de vós, abans dels segles concebuda, qu·à fet tornar en amor nostres ires (Serafí 2001: 335)

In these verses, the angels celebrate Mary's birth, as it meant the beginning of the history of Christ's salvation. On the other hand, if Mary is supposed to be essential for redemption, the popular thought was that she should occupy no other than Lucifer's chair, which is the content of the following anonymous poem published in the Cancionero espiritual in 1549:

\author{
Reyna de gran excelencia \\ delante cuya presencia \\ todas con gran reuerencia \\ cantan dulces melodías. \\ Emperatriz sublimada \\ quel humil obedescer, \\ te tiene agora assentada \\ sobre la silla ensalçada \\ de do cayó Lucifer. (Wardropper 1954: 41)
}

Pere Serafí expressed the same idea when saying that Mary's pregnancy meant the early stage of salvation:

Del moviment d'aquella guerra, alt en lo cel, per Lucifer maligne, caent, los mals ompliren mar y terra; hont los ellets per destruir tal herra, agenollats davant l'Etern benigne, tots esperant, Maria saludable, vostre venir, per reparar l'Altisme, verge parint Jesús, fill tan amable, y fent-s[e] al món als hòmens conversable, aquells tragués de l'infernal abisme. (Serafí 2001: 332)

It seems certain that Vives was very familiar with the motif of the fallen angels' chairs, using it repeatedly in his works. He might have known it in his native Valencia. Thus, he was likely to be crucial in spreading the idea among adherents of Spanish Humanism. This fact could explain how this metaphor frequently encountered in Valencian poetry would reappear in Castilian works in the sixteenth century. One relevant example is the passage from Martín Reyna's Dechado (1952: $\mathrm{LIVv}^{\circ}-\mathrm{LVr}^{\circ}$ ), quoted above, in which the fable of Orpheus and Eurydice was used to describe the relationship between God and his 
believers. This was an addition by Reyna, but its content also seems to be rooted in Valencia, concretely in Andreu Onorat Pineda, who compared redemption 'guanyem l'alta cadira' - to the sounds of Orpheus' lyre:

Continuau tals actes y exercicis

perquè sonem d'Orfeo la gran lyra,

y corregiu tots nostres crims y vicis

perquè, donats als literals officis,

d'onra y virtut guanyem l'alta cadira (Ferrando 1983: 838)

The similarities of thought and wording between one text pertaining to the Valencian poetry of the fifteenth century and another from Spanish Humanism can be better understood when considering Vives as a Valencian native and as a Spanish Humanist forming part of the European Erasmian movement. This dual role turned Vives into the main communication link between the Spanish and European Humanism of the sixteenth century. The allegory in question is a simple detail evidencing Vives' relevant position in the unfolding of Spanish Humanism from his way of conjugating the different Spanish native traditions, that is, Valencian culture and the European trends of thought in the sixteenth century.

\section{Works cited}

Alejos Morán, Asunción, 2005. 'Valencia y la Inmaculada Concepción: expresión religiosa a través de códices, libros, documentos y grabados', in La Inmaculada Concepción en España: religiosidad, historia y arte. Actes del Simposium 1/4-IV-2005, ed. Francisco Javier Campos and Fernandez de Sevilla (San Lorenzo de El Escorial: Real Centro Universitario Escorial/ María Cristina/ Ediciones Escurialenses), II, pp. 807-842.

Arronis Llopis, Carme (ed.), 2015 [1494]. La vida de la sacratíssima Verge Maria de Miquel Peres. (Alacant-Barcelona: Institut Interuniversitari de Filologia Valenciana-Publicacions de l'Abadia de Montserrat/ Biblioteca Sanchis Guarner, 84).

Bataller Catalá, Alexandre, 2000. 'Les traduccions castellanes del Liber de moribus de Jacobus de Cessulis', in Actas del VIII Congreso Internacional de la Asociación Hispánica de Literatura medieval, Santander 22-26 de septiembre de 1999 (Santander: Asociación Hispánica de Literatura Medieval), pp. 336-52. Available at: <http://www.ahlm.es/IndicesActas/ActasPdf/ Actas8.1/28.pdf> [accessed 18 May 2018].

-, 2009. 'Les traduccions del "Liber de moribus hominum et officiis nobilum (sic) super ludum scaccorum" de J. de Cessulis', Doctoral thesis, Universitat de València. Available at: https://www.tdx.cat/ handle/10803/9811 [accessed 14 June 2018].

Bono, Dianne M., 1991. Cultural Diffusion of Spanish Humanism in New Spain: Francisco Cervantes de Salazar's Diálogo de la dignidad del hombre (New York: Peter Lang).

Burt, Sister Marie Anita, 1957. Jacobus de Cessolis, Libellus de moribus hominum et officiis nobilium ac popularium super ludo schachorum, Ph.D thesis, University of Texas.

Callado Estela, Emilio, 2013. 'Justas, votos y fundaciones. Valencia y la Inmaculada en la primera época moderna', eHumanistal IVITRA, 3: 86-103. Available at: <http://www. ehumanista.ucsb.edu/sites/secure.1sit.ucsb.edu.span.d7_eh/files/sitefiles/ivitra/volume3/6_ callado_estela.pdf> [accessed 18 May 2018].

Cervantes Saavedra, Miguel de, 1999 [1617]. Los trabajos de Persiles y Sigismunda, ed. Florencio Sevilla Arroyo and Antonio Rey Hazas (Madrid: Alianza Editorial).

Cervantes de Salazar, Francisco, 1971. Crónica de la Nueva España, ed. Manuel Magallón, estudio preliminar e índices de Agustín Millares Carlo (Madrid: Atlas). 
-, 1986. Commentaria in Lodovici Vives exercitationes linguae latinae, ed. Margarita Peña, trans. Joaquín García Icazbalceta (México: Trillas).

Cessolis, Jacobus de, 1879 [c.1425-1450]. 'Liber de Moribus hominum ac officiis nobilium sive super ludum scaccorum', Jahresbericht der Mitteilungen aus den Hadschriften der Ritter Akademie zu Brandenburg, ed. Ernst Köpke (Brandenburg: Verlag von Adolph Müller).

,- 1900 . De les costumes dels homens e dels oficis dels nobles, ed. Josep Brunet (Barcelona: l'Avenç).

-, 1902. Libre de bones costumes dels homens e dels oficis dels nobles, ed. Antoni Bulbena (Barcelona: Francisco X. Altés).

-, 2005. El juego del ajedrez o dechado de fortuna, ed. Marie-José Lemarchand (Madrid: Siruela).

Clausell Nácher, Carmen (ed.), 2007. Carro de las donas, adaptación del Llibre de les dones de Francesc Eiximenis OFM realizada por el P. Carmona OFM. 2 vols. (Madrid: FUE/ Universidad Pontificia de Salamanca).

Colahan, Clark, and Roberto Masferrer, 2007. Díaz de Luco's Guide for Bishops. Spanish Reform and the Lazarillo (Tempe, AZ: Arizona Center for Medieval and Renaissance Studies).

Coronel Ramos, Marco Antonio, 2012. 'Juan Luis Vives y el Lazarillo de Tormes', eHumanista/ IVITRA, 1: 42-83. Available at: <http://www.ehumanista.ucsb.edu/sites/secure.lsit.ucsb.edu. span.d7_eh/files/sitefiles/ivitra/volume1/4\%20ehumanista.ivitra.coronel.lazarillo.definitivo.pdf> [accessed 18 May 2018].

-, 2013. 'La caridad: voces de reforma del clero en el siglo XVI', Studia Philologica Valentina, 15: 169-88. Available at: http://roderic.uv.es/handle/10550/35047 [accessed 14 June 2018].

-, 2018. 'Angelología y antropología a principios de la modernidad', in La Raison du merveilleux, ed. Dominique de Courcelles (Paris: Garnier).

Deffis de Calvo, Emilia I., 1999. Viajeros, peregrinos y enamorados: la novela de peregrinación del siglo XVII. Anejos de RILCE 28. (Pamplona: EUNSA), pp. 67-96.

Díaz de Luco, Juan Bernal, 1530. Instructión de Perlados o Memorial breue de algunas cosas que deuen hazer para el descargo de sus conciencias y buena gouernación de sus Obispados y Diócesis (Alcalá: Miguel de Eguía).

-, 1962 [1550]. Soliloquio y Carta desde Trento, ed. Tomás Marín Martínez (Barcelona: Juan Flors).

-, 1996 [1543]. Aviso de curas, ed. José Luis Tejada Herce (Madrid: FUE-Universidad Pontificia de Salamanca).

Eiximenis, Francesc, 1958. Cercapou, ed. G. E. Sansone. 2 vols. (Barcelona: Barcino).

-, 1981 [1542]. Lo libre de les dones, ed. Frank Naccarato, rev. Curt Wittlin. 2 vols. (Barcelona: Universitat de Barcelona, Curial-Departament de Filologia Catalana).

-, 1988. De sant Miquel Arcàngel. El quint tractat del Libre dels àngels, ed. Curt Wittlin (Barcelona: Curial).

Erasmo de Rótterdam, Desiderio, 1975. La lengua, nuevamente romançada por muy elegante estilo, traducción de Bernardo Pérez de Chinchón, ed. Dorothy S. Severin (Madrid: Anejos del Boletín de la Real Academia Española, v. XXXI).

Ferrando Francés, Antoni, 1983. Els certàmens poètics valencians (València: Institució Alfons el Magnànim).

Forcione, Alban K., 1972. Cervantes' Christian Romance. A Study of Persiles y Sigismunda (Princeton, NJ: Princeton University Press).

Fradejas Lebrero, José, 2005. Los evangelios apócrifos en la literatura española (Madrid: BAC Editorial).

Garcia Sempere, Marinela (ed.), 2002 [1493]. Lo Passi en cobles. Prologue Antoni Ferrando (AlacantBarcelona: Institut Interuniversitari de Filologia-PAM).

Gassull, Jaume, 1989. Obra religiosa, ed. Rosanna Cantavella i Salvador Jàfer (València: Ed. Alfons el Magnànim/ Institució valenciana d'estudis i investigación).

Gernert, Folke (ed.), 2002. Baldo, Sevilla, Dominico de Robertis, 1542 (Alcalá de Henares: Centro de Estudios Cervantinos).

Gómez Marín, José Antonio, 2001. Juan Bernal Díaz de Luco: un obispo reformista entre Loyola y Erasmo. Lección inaugural del curso académico Aula de Mayores y de la Experiencia 2001-2002 (Huelva: Universidad de Huelva, Servicio de Publicaciones).

Izquierdo Gil, Josep, 1997. 'The Evangelium Nicodemi in Medieval Catalan and Occitan Literature', 
in The Medieval Gospel of Nicodemus: Texts, Intertexts, and Contexts in Western Europe, ed. Zbigniew S. Izydorczyk (Tempe: Arizona Board of Regents), pp. 133-64.

López Quiles, Antoni, and Abel Puig Gisbert, 2014. Ensenyar, commoure i adelitar. Notes de propedèutica per a rellegir Corella (Valencia: Perifèric Edicions).

Llull, Ramon, 1987 [?1274-1276]. Doctrina Pueril, ed. Gret Schib (Barcelona: Barcino).

Reyna, Martín, 1952. Dechado de la vida humana moralmente sacado del juego de axedrez. Facsimile of the Valladolid edition of 1549 printed by Fernández de Córdoba (Valencia: Castalia).

Rodríguez-Moñino, Antonio (ed.), 1970. Silva de Romances, Zaragoza 1550-1551, ahora por vez primera reimpresa desde el siglo XVI en presencia de todas las ediciones (Zaragoza: Publicaciones de la Cátedra Zaragoza).

Roís de Corella, Joan, 2014. Obra completa, ed. Vicent Escartí (Valencia: Institución Alfons el Magnànim).

Ruiz-Gálvez Priego, Estrella, 2006. 'La Inmaculada, emblema de la firmeza femenina', ARENAL, 13.2: 291-310.

-, 2008. 'Sine Labe. El inmaculismo en la España de los siglos XV al XVII. La proyección social de un imaginario religioso', Revista de Dialectología y Tradiciones Populares, 63.2: 197-241.

Sanchis Guarner, Manuel (ed.), 1974 [1474]. Les trobes en lahors de la Verge María, Valènci. Edició facsímil amb estudi preliminar i transcripció (Valencia: Caixa d’Estalvis i Mont de Pietat de València).

Scolari, Antonio, 1989. 'I volgarizzamenti del Libellus super ludo scaccorum (prime indagine sulla tradizione)', Studi di Filologia Italiana, 47: 31-99.

—, 2001. 'I volgarizzamenti del Libellus super ludo scaccorum. La redazione A: analisi della tradizione e saggio di edizione critica', Studi di Filologia Italiana, 59: 9-78.

Serafí, Pere, 2001. Poesies catalanes, ed. Josep Romeu i Figueras (Barcelona: Barcino).

Stratton, Suzanne L., 1989. La Inmaculada Concepción en el arte español, trans. José. L. Checa Cremades (Madrid: Fundación Universitaria Española).

Twomey, Lesley K., 2013. The Fabric of Marian Devotion in Isabel de Villena's Vita Christi (Woodbridge, UK: Tamesis).

Villena, sor Isabel de, 2011 [1497]. Vita Christi, ed. Vicent J. Escartí, presentació de Pere Maria Orts i Bosch (Valencia: Institució Alfons el Magnànim).

Vives, Juan Luis, 1544. Introducción para ser sabio, buelta en castellano por Francisco Ceruantes de Salazar (Seville: Dominico de Robertis).

-, 1782 [1518]. 'Meditationes in septem psalmos quos vocant poenitentiae', in Opera Omnia, distributa et ordinata a Gregorio Majansio (Valencia: Monfort), I, pp. 162-255.

-, 1783. 'Fabula de homine', in Opera Omnia, distributa et ordinata a Gregorio Majansio (Valencia: Monfort), IV, pp. 1-8.

-, 2009 [1529]. Diálogo de doctrina Christiana, ed. and intro. Francisco Calero and Marco Antonio Coronel Ramos (Madrid: UNED-BAC).

Wittlin, Curt, 1983. 'La primera adaptación castellana de Lo llibre de les dones de Francesc Eiximenis', Miscel-lània Pere Bohigas. 3. Estudis de llengua i literatura catalanes VI. (Barcelona: PAM), pp. 39-59.

Wardropper, Bruce W. (ed.), 1954. Cancionero espiritual impreso en Valladolid en casa de Juan de Villaquirán 1549 (Valencia: Castalia). 
